\title{
IKK $\beta$ in intestinal epithelial cells regulates allergen-specific IgA and allergic inflammation at distant mucosal sites
}

\author{
A Bonnegarde-Bernard ${ }^{1,2}, \mathrm{~J} \mathrm{Jee}^{1}, \mathrm{MJ} \mathrm{Fial}^{1}, \mathrm{~F}$ Aeffner$^{1}, \mathrm{E}$ Cormet-Boyaka ${ }^{3}$, IC Davis ${ }^{1}, \mathrm{M} \mathrm{Lin}^{1}$, \\ D Tomé2, M Karin ${ }^{4}$, Y Sun ${ }^{5}$ and PN Boyaka ${ }^{1,3}$
}

Regulation of allergic responses by intestinal epithelial cells (IECs) remains poorly understood. Using a model of oral allergen sensitization in the presence of cholera toxin as adjuvant and mice with cell-specific deletion of inhibitor-кB kinase (IKK $\beta$ ) in IECs (IKK ${ }^{\Delta \mathrm{IEC}}$ ), we addressed the contribution of IECs to allergic sensitization to ingested antigens and allergic manifestations at distant mucosal site of the airways. Cholera toxin induced higher pro-inflammatory responses and altered the profile of the gut microbiota in IKK $\beta^{\Delta I E C}$ mice. Antigen-specific immunoglobulin $E(\lg E)$ responses were unaltered in IKK $\beta^{\Delta I E C}$ mice, but their IgA antibodies (Abs), T helper type 1 (Th1) and Th17 responses were enhanced. Upon nasal antigen challenge, these mice developed lower levels of allergic lung inflammation, which correlated with higher levels of IgA Abs in the airways. The IKK $\beta^{\Delta \mathrm{IEC}}$ mice also recruited a higher number of gut-sensitized Tcells in the airways after nasal antigen challenge and developed airway hyper-responsiveness, which were suppressed by treatment with anti-interleukin-17A. Fecal microbiota transplant during allergic sensitization reduced Th17 responses in $I K K \beta^{\Delta I E C}$ mice, but did not affect IgA Ab responses. In summary, we show that IKK $\beta$ in IECs shapes the gut microbiota and immune responses to ingested antigens and influences allergic responses in the airways via regulation of $\lg A \mathrm{Ab}$ responses.

\section{INTRODUCTION}

Ingestion of food antigens generally fails to promote brisk immune responses but rather results in a state of immune tolerance. However, aberrant immune responses, including food allergy, can develop in individuals with a genetic predisposition. Clinical manifestations of food allergies include gastrointestinal, systemic (anaphylaxis), cutaneous (eczema), or respiratory (asthma) symptoms ${ }^{1,2}$ and are generally regarded as pathological responses to food antigens mediated by excessive Thelper type 2 (Th2) responses and antigen-specific immunoglobulin $\mathrm{E}$ ( $\mathrm{IgE}$ ) antibody ( $\mathrm{Ab})$ responses. Past research on allergy and asthma focused on the role of cells and molecules involved in adaptive immunity. More recently, epithelial cells lining the sites of antigen entry and innate immune responses have emerged as important players in these pathologies. ${ }^{1,3,4}$ Studies in animal models have demonstrated that oral sensitization to allergens primes for adverse inflammatory responses at distant sites of the airways or the skin. ${ }^{5,6}$ However, little is known about the mechanism(s) employed by intestinal epithelial cells (IECs) to shape immune responses to allergens and influence allergic manifestations in distant mucosal sites, such as the airways.

The nuclear factor- $\kappa \mathrm{B}(\mathrm{NF}-\kappa \mathrm{B})$ pathway has an important role in inflammatory responses. ${ }^{7}$ Its activation is regulated by the inhibitor- $\kappa B$ kinase (IKK $\beta$ ), the catalytic subunit of the IKK complex responsible for NF- $\kappa \mathrm{B}$ translocation and transcription. $^{7}$ Previous studies have shown that the IKK $\beta-N F-\kappa B$ signaling controls a number of biological processes via tissuespecific regulation of inflammatory and anti-inflammatory responses and can mediate both pro- and anti-inflammatory effects. ${ }^{8,9}$ These opposite effects were attributed to the nature of immune cells where the IKK $\beta$-NF- $\kappa B$ signaling was affected. ${ }^{10}$

${ }^{1}$ Department of Veterinary Biosciences, The Ohio State University, Columbus, Ohio, USA. ${ }^{2}$ Laboratory of Human Nutrition, Agro Paris Tech, Paris, France. ${ }^{3}$ Department of Internal Medicine, The Ohio State University, Columbus, Ohio, USA. ${ }^{4}$ Department of Pharmacology, University of California, La Jolla, California, USA and ${ }^{5}$ Research and Testing Laboratory, Lubbock, Texas, USA. Correspondence: PN Boyaka (boyaka.1@osu.edu) 
However, both attenuation of chronic and exacerbation of acute gut inflammatory diseases were reported in mice with alteration of IKK $\beta$-dependent NF- $\kappa B$ activation in IECs. ${ }^{11}$ Others have shown that inhibition of IKK $\beta$-dependent NF- $\kappa B$ activation limits the production of Th2-inducing cytokine by IECs and, thus, impairs the development of protective immunity against the gut-dwelling parasite, Trichuris. ${ }^{12}$

The large intestine of mammals contains a huge community of commensal bacteria, which contributes to the digestive functions, ${ }^{13}$ prevent the development of inflammatory bowel diseases, ${ }^{14}$ and support the maturation of gut immune cells. ${ }^{15,16}$ The gut microbiota can be perturbed by endogenous or exogenous factors and it is now established that microbial dysbiosis is associated with allergy, ${ }^{17,18}$ obesity, ${ }^{19}$ and inflammatory diseases. ${ }^{20,21}$ IECs sense changes in gut microbiota, and transplantation of healthy infant gut microbiota could protect mice from developing allergic responses to food antigens. ${ }^{17}$

Oral administration of food antigen with cholera toxin as adjuvant in experimental animals is a well-accepted model to study allergic sensitization to food antigens. ${ }^{5,6,22}$ To address the role of IECs in pathogenic immune responses to ingested food antigens, mice with targeted deletion of IKK $\beta$ in IECs $\left(\mathrm{IKK} \beta^{\Delta \mathrm{IEC}}\right)^{23}$ were orally sensitized to a food antigen in the presence of cholera toxin. We show that a localized impairment of IKK $\beta$ in IECs alters the gut microbiota during oral allergic sensitization and regulates the profile of allergic inflammatory responses at the distant airways through IgA Abs and Th17 responses.

\section{RESULTS}

IKK $\beta$ deletion in IECs enhances gut inflammatory responses to the adjuvant cholera toxin

Sixteen hours after oral cholera toxin treatment, phosphonuclear factor- $\kappa \mathrm{B}$ (pNF- $\mathrm{kB}$ ) expression was enhanced in IECs of $\mathrm{C} 57 \mathrm{BL} / 6$ mice and primarily found in the nucleus. Cholera toxin also increased pNF- $\kappa B$ expression in IECs of IKK $\beta^{\Delta \mathrm{IEC}}$ mice, but the localization was primarily cytoplasmic (Figure 1). Except for thymic stromal lymphopoietin (TSLP) mRNA levels that were lower in the IKK $\beta^{\Delta \mathrm{IEC}}$ group, we found no difference between control and IKK $\beta^{\Delta \mathrm{IEC}}$ mice before treatment. Cholera toxin elevated mRNA levels of the pro-inflammatory cytokines in both IKK $\beta^{\triangle \mathrm{IEC}}$ mice and control C57BL/6 mice, but tumor necrosis factor- $\alpha$ (TNF- $\alpha$ ) mRNA levels were increased by $\sim 10$-fold in IKK $\beta^{\triangle \mathrm{IEC}}$ mice (Figure 1b). Cholera toxin also significantly increased transforming growth factor- $\beta$ (TGF- $\beta$ ) mRNA levels in the gut of IKK $\beta^{\Delta \text { IEC }}$ mice (Figure 1b). At the time point examined, cholera toxin treatment did not change TSLP mRNA levels in the gut of control mice but raised TSLP mRNA levels in IKK $\beta^{\triangle \mathrm{IEC}}$ mice (Figure 1b). The enhanced level of cytokine mRNA responses in the gut of IKK $\beta^{\Delta \mathrm{IEC}}$ mice was associated with higher levels of pSTAT3 (phosphorylated signal transducer and activator of transcription factor 3 ) responses as determined by western blotting (Figure 1c) and immunohistochemistry (Supplementary Figure S1 online).

\section{Loss of IKK $\beta$ in IECs favors dysbiosis in cholera toxin-treated mice}

Unlike controls, IKK $\beta^{\Delta \mathrm{IEC}}$ mice showed no signs of intestinal fluid accumulation $16 \mathrm{~h}$ after treatment with cholera toxin (Supplementary Figure S2 online). Analysis of bacterial 16S rRNA genes in fecal pellets showed no significant difference between the ratios of Bacteroidetes and Firmicutes phyla in controls and IKK $\beta^{\triangle \mathrm{IEC}}$ mice before cholera toxin treatment (Figure 2a and Supplementary Table S1). Four days after oral administration of cholera toxin, a dysbiosis affecting phyla (Figure 2a), class (Figure 2b), and species (Figure 2b) was observed in the fecal pellets of IKK $\beta^{\Delta \mathrm{IEC}}$ mice (details in Supplementary Figures S3-S5 and Supplementary Tables S1-S6 online).

\section{Loss of IKK $\beta$ in IECs alters antigen-specific CD4 ${ }^{+} \mathrm{T}$-cell and Ab responses to oral sensitization}

Segmented filamentous bacteria (SFB) are noncultivable commensal Gram-positive anaerobic bacteria that share strong $16 \mathrm{~S}$ rRNA similarities with the genus Clostridium ${ }^{24-26}$ and regulate Th cytokine responses. ${ }^{27,28}$ Four days after oral administration of cholera toxin, the percentage of SFB was slightly increased in controls but was significantly elevated in IKK $\beta^{\Delta \mathrm{IEC}}$ mice (Figure 3a).

We next examined whether innate cytokine responses and dysbiosis in the gut of IKK $\beta^{\Delta \mathrm{IEC}}$ mice were associated with changes in allergen-specific Th cytokine and $\mathrm{Ab}$ responses. Mesenteric lymph node (MLN) and spleen T cells from control and IKK $\beta^{\Delta \mathrm{IEC}}$ mice secreted the same level of interleukin (IL)-4 after in vitro restimulation with ovalbumin (OVA; data not shown). On the other hand, IL- 5 and IL-10 secretion by cells from IKK $\beta^{\Delta \mathrm{IEC}}$ mice were significantly decreased (Figure $3 \mathbf{b}$ ), while IL-17 and interferon (IFN) $-\gamma$ responses were both enhanced (Figure 3b). Th1-associated IgG2a (IgG2c) responses were significantly enhanced in IKK $\beta^{\Delta \mathrm{IEC}}$, whereas $\operatorname{IgE}$ and IgG1 Ab responses were unchanged (Figure 3c). In addition, IKK $\beta^{\Delta \mathrm{IEC}}$ mice developed higher OVA-specific $\operatorname{IgA~} \mathrm{Ab}$ responses than control C57BL/6 mice.

To clarify whether the changes in cytokine and Ab levels were the result of a changed microbiome or were a consequence of the lack of IKK $\beta$ in epithelial cells, microbiome swap was performed by fecal microbiome transplant 4 days after each oral sensitization (Figure 4a). The fecal microbiome swap affected antigen-specific T-cell cytokine responses by MLN cells as it reduced IL-17A responses of IKK $\beta^{\mathrm{IEC}}$ when compared with wild-type mice and eliminated the difference between the levels of IL-5 and IL-10 responses between these mice (Figure $4 \mathbf{b}$ ). Interestingly, IKK $\beta^{\Delta \mathrm{IEC}}$ mice recipient of fecal microbiome transplant from orally sensitized wild-type mice retained higher levels of serum IgA responses (Figure 4c). These results suggest that intestinal dysbiosis in IKK $\beta^{\Delta \mathrm{IEC}}$ mice alters antigen-specific $\mathrm{CD} 4{ }^{+} \mathrm{T}$-cell responses while IKK $\beta$ in IECs primarily regulates IgA Ab levels.

To further establish how local (gut) vs. systemic (circulating myeloid cells) alteration of IKK $\beta$ affected allergen-specific $\mathrm{Ab}$ responses, we analyzed these responses in mice lacking 
a

C57BL/6

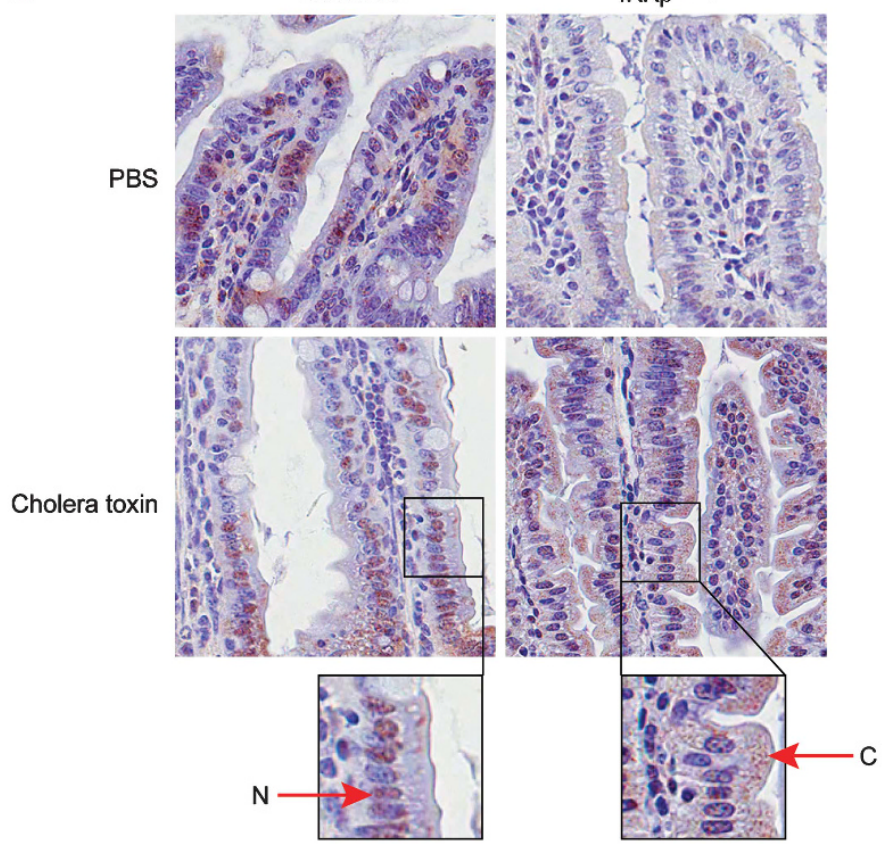

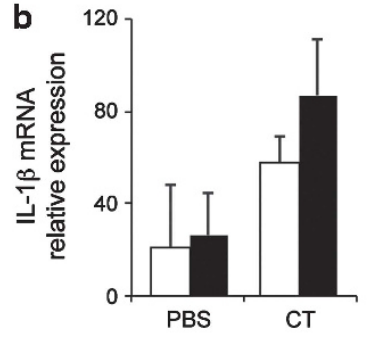
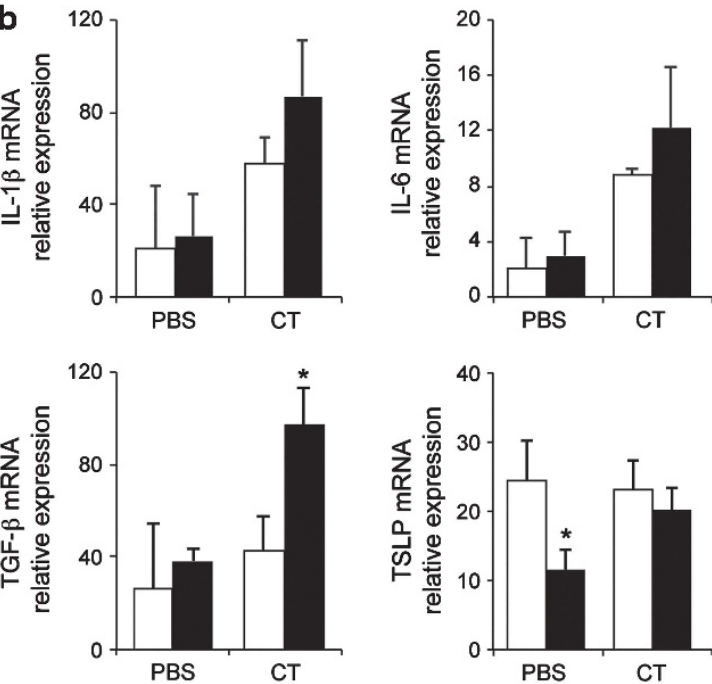

c
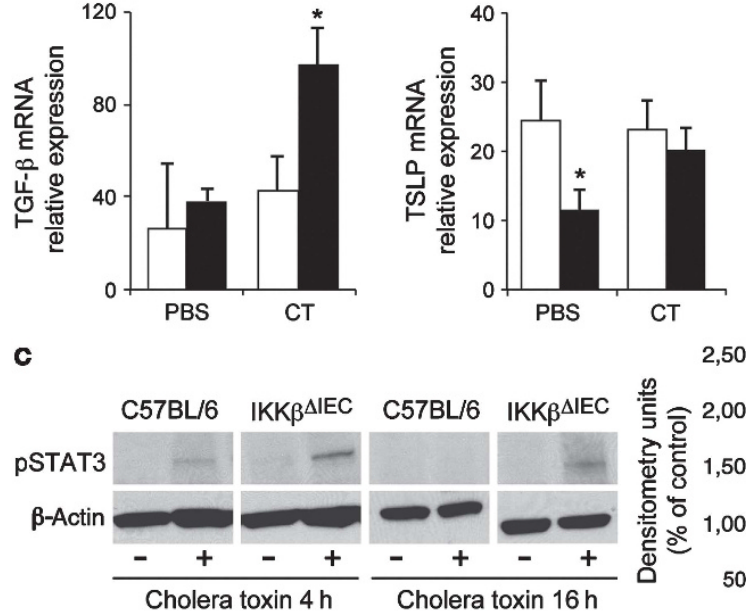

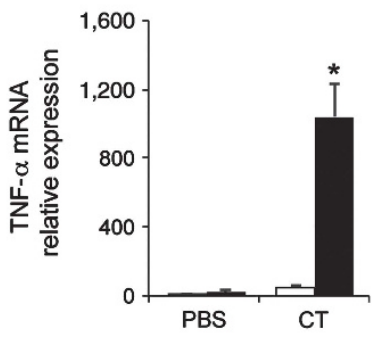

C57BL/6

$\mathrm{IKK} \beta^{\Delta \mathrm{IEC}}$

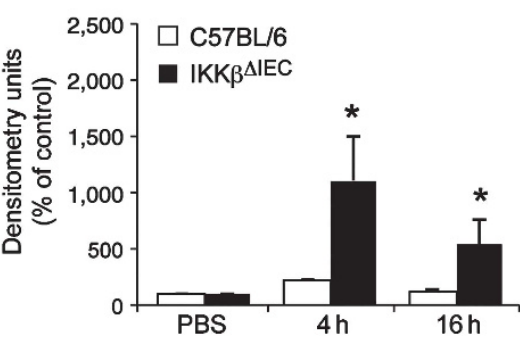

Figure 1 Innate responses to cholera toxin (CT) in intestinal tissues of IKK $\beta^{\Delta \mathrm{IEC}}$ (deletion of inhibitor-KB kinase (IKK $\beta$ ) in intestinal epithelial cells (IECs)) mice. Mice were orally administered cholera toxin $(10 \mu \mathrm{g}$ ) by gavage, and small intestines were collected 4 or $16 \mathrm{~h}$ later. (a) Phospho-nuclear factor (pNF)$\kappa B$ expression $16 \mathrm{~h}$ after administration of saline (phosphate-buffered saline (PBS)) or cholera toxin. Tissue sections were labeled with anti-pNF-кB p65 Ab and counter-stained with hematoxylin and eosin. Each image $(\times 400)$ is representative of at least three independent experiments. Higher magnifications show pNF-кB p65 expression in the nucleus (N) and cytoplasma (C) of epithelial cells (b) Real-time reverse transcriptase-PCR analysis of cytokine mRNA. Data are expressed as mean relative expression levels \pm 1 s.d. (c) Western blot analysis of phospho-signal transducer and activator of transcription factor 3 (pSTAT3) expression and quantification of relative pSTAT3 expression as mean densitometry units. Data are from four separate experiments $\left({ }^{*} P<0.05\right)$. IL, interleukin; TGF, transforming growth factor; TNF, tumor necrosis factor; TSLP, thymic stromal lymphopoietin. 


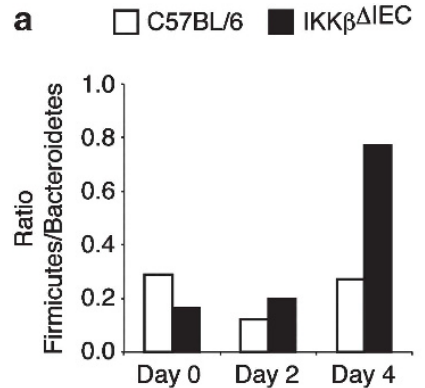

C

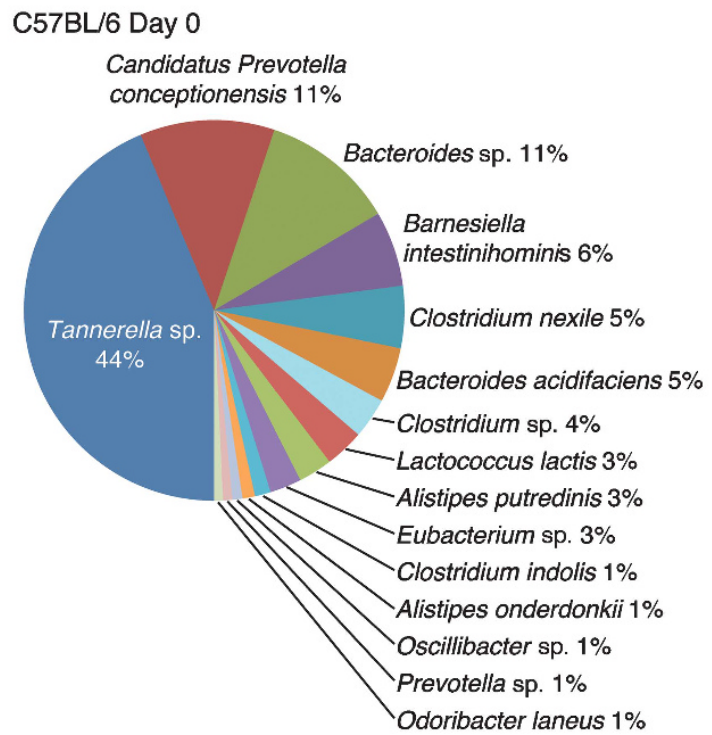

IKK $\beta \Delta$ IEC Day 0

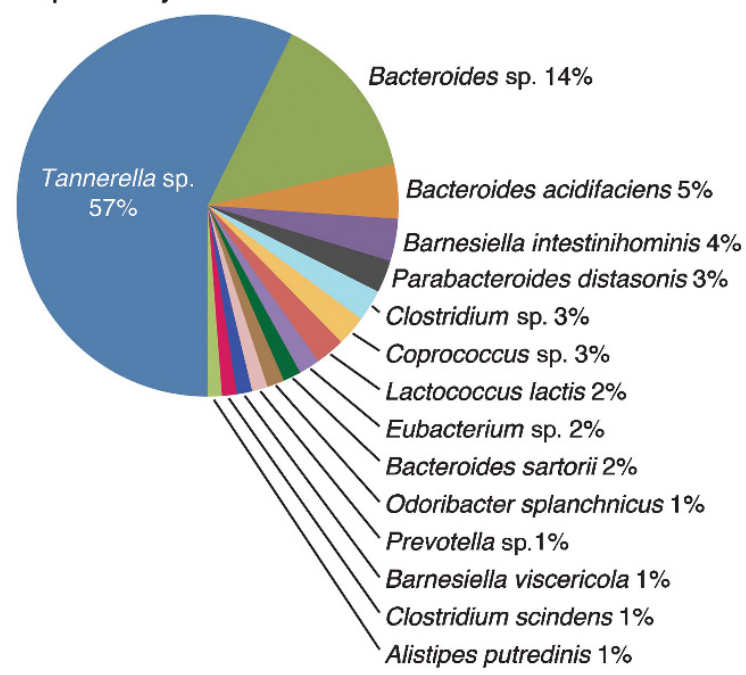

b $\square \mathrm{C} 57 \mathrm{BL} / 6 \square \mathrm{IKK} \beta \Delta \mathrm{IEC}$

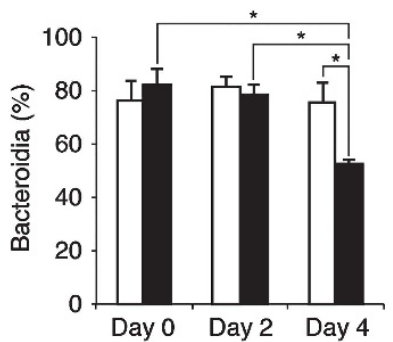

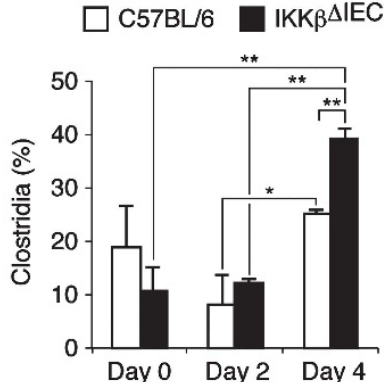

$\square$ C57BL/6

$\mathrm{IKK} \beta \Delta \mathrm{IEC}$

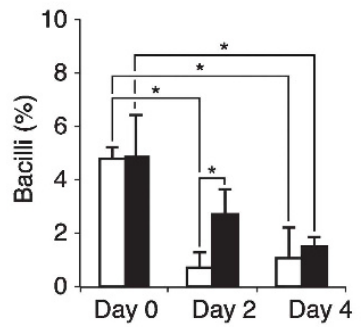

\section{C57BL/6 Dav 4}

\section{Candidatus Prevotella conceptionensis $17 \%$}

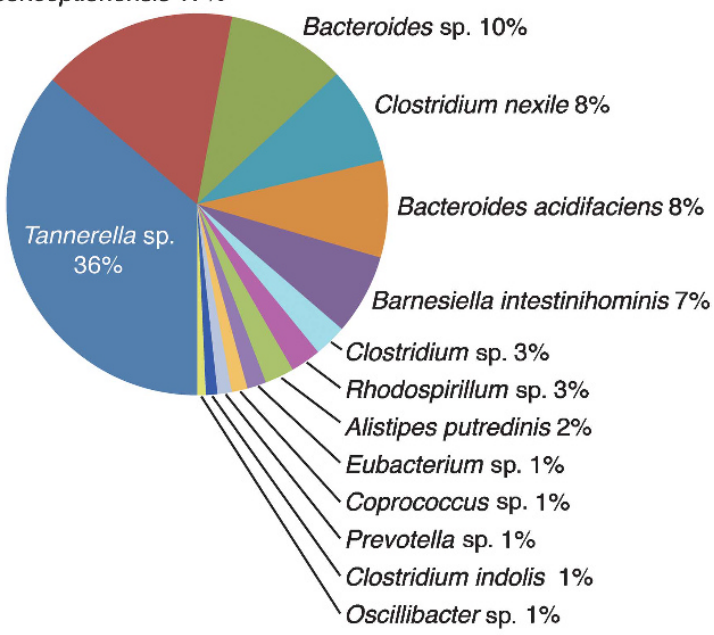

IKK $\beta \Delta \mathrm{IEC}$ Day 4

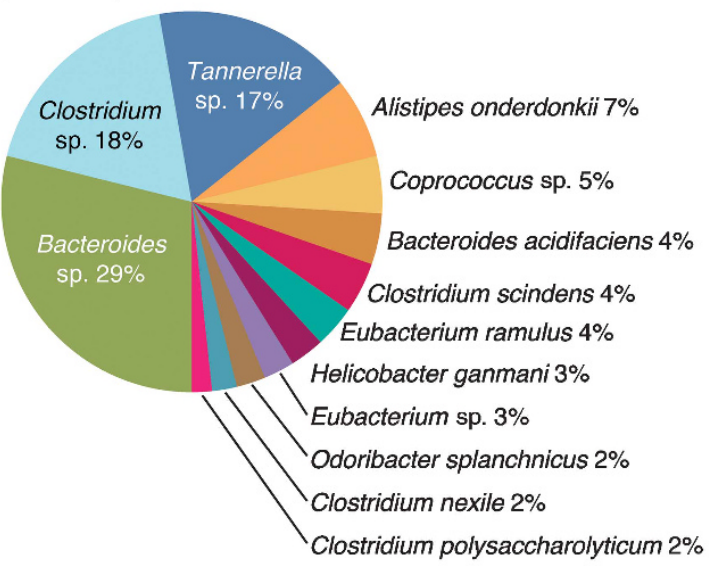

Figure 2 Cholera toxin alters the gut microbiota in IKK $\beta^{\Delta \mathrm{IEC}}$ (deletion of inhibitor- $\kappa B$ kinase (IKK $\beta$ ) in intestinal epithelial cells (IECs)) mice. Bacterial flora was analyzed in fecal pellets collected before (day 0 ) and 2 and 4 days after administration of cholera toxin. (a) Ratio of main bacteria Phyla, (b) percentage of main bacteria genus, (c) pie diagrams of the 15-17 main bacteria species. The results in $\mathbf{b}$ are expressed as mean percentage \pm 1 s.d. $\left({ }^{\star} P<0.05 ;{ }^{* *} P<0.01\right)$. All results were from $3-4$ mice per groups.

IKK $\beta$ in myeloid cells $\left(\operatorname{IKK} \beta^{\Delta \text { Mye }}\right.$ ) throughout the body. ${ }^{8}$ These mice showed higher pSTAT3 responses in the small intestine than C57BL/6 mice $16 \mathrm{~h}$ after oral administration of cholera toxin and developed higher levels of antigen-specific Th1-associated IgG2a (IgG2c) responses (Supplementary Figure $\mathbf{S 6}$ online). The OVA-specific IgE and $\operatorname{IgG} 1 \mathrm{Ab}$ responses were unchanged in $\mathrm{IKK} \beta^{\Delta \text { Mye }}$ mice, whereas IgA responses were enhanced, although not to the same extent as in IKK $\beta^{\triangle I E C}$ mice (Supplementary Figure S6 online). Thus, IKK $\beta$ signaling in either epithelial cells or circulating myeloid cells regulates $\mathrm{Ab}$ responses to ingested allergens. 


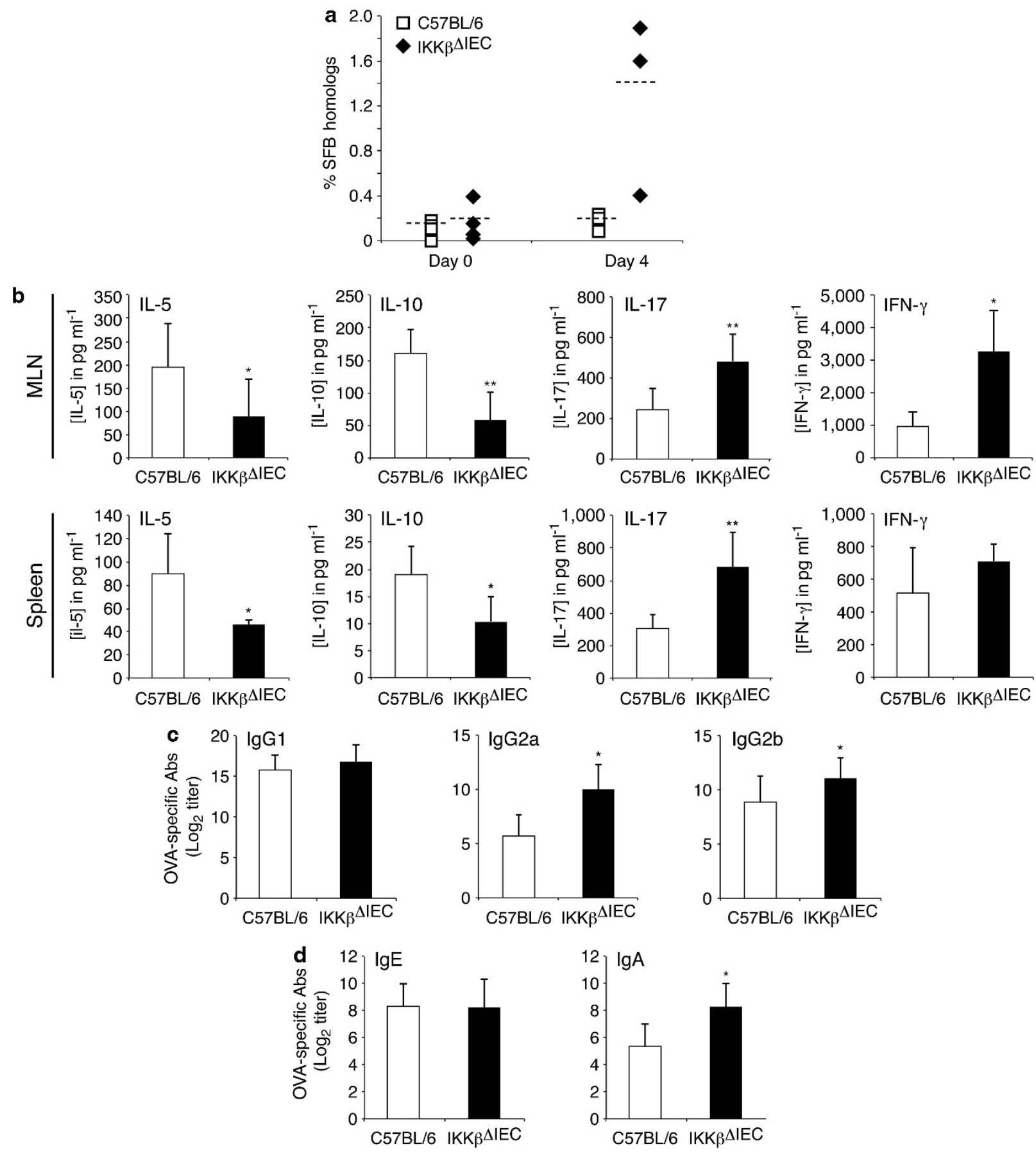

Figure 3 Inhibitor-KB kinase (IKK $\beta$ )-deficiency in intestinal epithelial cells (IECs) alters the profile of antigen-specific CD4 ${ }^{+} \mathrm{T}$ cell and serum antibody (Ab) responses in orally sensitized mice. (a) Percentage of segmented filamentous bacteria (SFB) homolog before (day 0 ) and 4 days after administration of cholera toxin. (b) Cytokine secretion by ovalbumin (OVA)-specific mesenteric lymph node (MLN) and spleen T cells were analyzed by enzyme-linked immunosorbent assay (ELISA). Results are expressed as mean \pm s.d. of three separate experiments, with four mice per group. ( ${ }^{\star} P<0.05 ;{ }^{\star \star} P<0.01$ compared with control C57BL/6 mice). (c) OVA-specific immunoglobulin G (IgG) subclass and (d) IgE and IgA isotypes. Blood was collected on day 14, and Ab titers were analyzed by ELISA. The results are expressed as the $\log _{2}$ titers \pm 1 s.d. and are from three experiments and five mice/group. ( ${ }^{\star} P<0.05$ compared with control C57BL/6 mice). IFN, interferon; IL, interleukin.

\section{Alteration of IKK $\beta$ signaling in IECs limits allergic inflammation in the airways}

Allergic inflammation can develop in the airways following nasal allergen challenge of mice sensitized by the oral route. ${ }^{5,6}$ Other reports have indicated that intestinal microbes influence susceptibility to food allergy ${ }^{29}$ and regulate immunity to respiratory influenza virus infection. ${ }^{30}$ Lung inflammation was not seen in naive (non-sensitized and not challenged), or challenged but not sensitized C57BL/6, IKK $\beta^{\Delta \text { Mye }}$ and IKK $\beta^{\Delta I E C}$ mice. Orally sensitized control C57BL/6 mice 

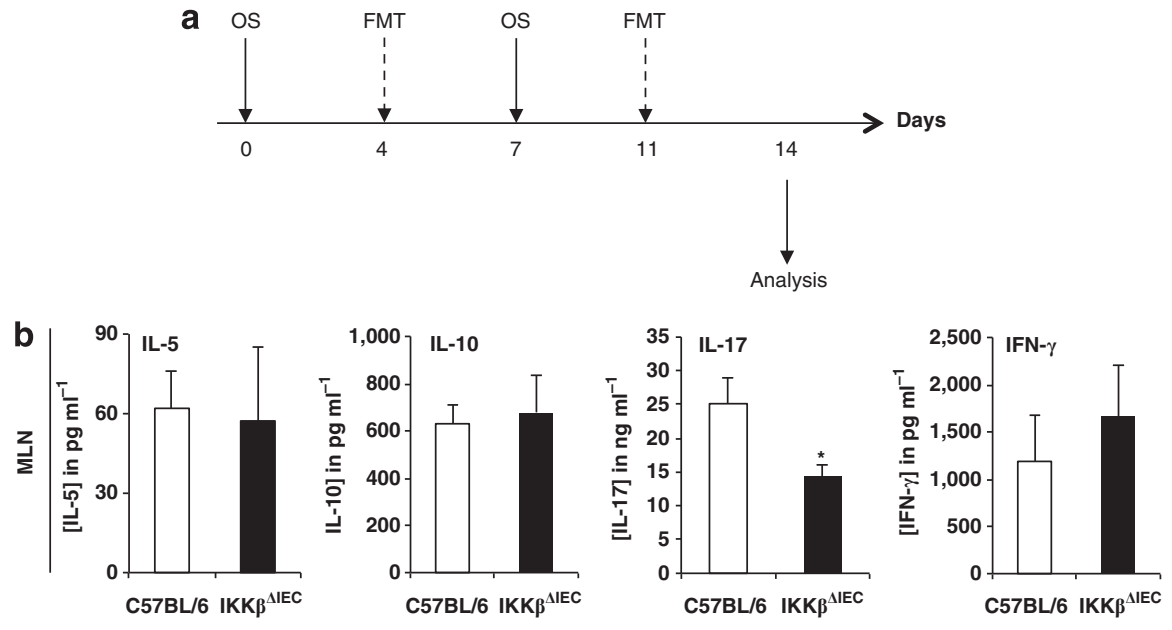

C
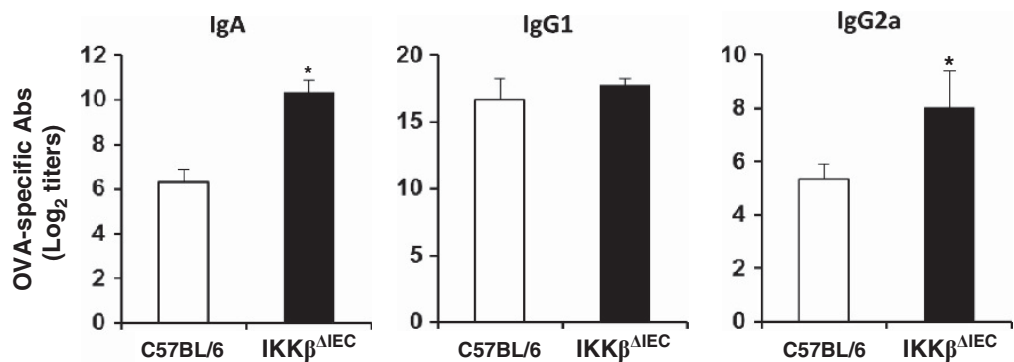

Figure 4 Fecal microbiota transfer (FMT) modulates antigen-specific CD4 ${ }^{+}$T-cell cytokines, but not serum immunoglobulin A (IgA) responses orally sensitized IKK $\beta^{\Delta \mathrm{IEC}}$ mice. (a) Schedule of oral sensitization (OS) and FMT. (b) Cytokine secretion by ovalbumin (OVA)-specific mesenteric lymph node (MLN) T cells were analyzed by enzyme-linked immunosorbent assay (ELISA). (c) OVA-specific IgG subclass and IgA responses. Blood was collected on day 14, and antibody (Ab) titers were analyzed by ELISA. The results are expressed as the log $\log _{2}$ titers $\pm 1 \mathrm{~s} . \mathrm{d}$. and are from three experiments and five mice/ group. ( ${ }^{\star} P<0.05$ compared with control C57BL/6 mice). IFN, interferon; IL, interleukin.

developed lung inflammation with cell recruitment in the lung parenchyma and the perialveolar and perivascular space after nasal antigen challenge (Figure $\mathbf{5 a}, \mathbf{b}$ ). Interestingly, lung inflammation was significantly reduced in $\mathrm{IKK} \beta^{\triangle \mathrm{IEC}}$ mice (Figure 5a,b) and in IKK $\beta^{\Delta \text { Mye }}$ mice (Figure 5a). Only minimal mucus formation was seen in the lungs of IKK $\beta^{\Delta \mathrm{IEC}}$ mice after antigen challenge and none in the lungs of IKK $\beta^{\Delta \text { Mye }}$ mice (Figure 5c). In contrast to $\mathrm{C} 57 \mathrm{~B} / 6$ mice or IKK $\beta^{\Delta M y e}$ mice, bronchoalveolar lavage (BAL) of IKK $\beta^{\Delta \mathrm{IEC}}$ mice contained higher levels of IgA (Figure 5d), and their lungs showed more IgA-secreting cells (Supplementary Figure $\mathbf{S 7}$ online). IgA Abs are believed to suppress allergic inflammation. ${ }^{31}$ The presence of IgA in BAL of IKK $\beta^{\triangle I E C}$ mice was associated with a reduction of eosinophils and macrophages, but the number of neutrophils was increased (Figure 5e). On the other hand, other mechanisms are likely involved in the protection of IKK $\beta^{\Delta \text { Mye }}$ mice, which exhibited overall lower number of cells in the lung after allergen challenges. In this regard, the proportion of $\mathrm{F} 4 / 80^{+} \mathrm{CD} 11 \mathrm{c}^{+}$alveolar macrophages after nasal challenge was reduced in IKK $\beta^{\Delta \mathrm{IEC}}$ when compared with control C57BL/6 mice ( $20 \pm 2.2 \%$ vs. $28 \pm 2.5 \%)$ (Supplementary Figure S8A online). Nasal challenge of orally sensitized control $\mathrm{C} 57 \mathrm{BL} / 6$ mice recruited $\mathrm{CD} 11 \mathrm{c}^{+} \mathrm{F} 4 / 80^{-}$ $\mathrm{CD} 103^{+}$cells in the lungs, an effect significantly reduced in mice with impaired IKK $\beta$ (Supplementary Figure S8B online). We also found a higher frequency of $\mathrm{CD}^{+}{ }^{+} \mathrm{T}$ cells in the lungs of IKK $\beta^{\Delta \mathrm{IEC}}$ mice than in control C57BL/6 or $\operatorname{IKK} \beta^{\Delta \mathrm{Mye}}$ mice after nasal challenge of orally sensitized mice (Supplementary Figure S8C online).

\section{Protection by IEC IKK $\beta$ requires oral sensitization}

To further establish the role played by IECs in protection of IKK $\beta^{\Delta \mathrm{IEC}}$ mice against allergic airway inflammation, mice were sensitized by intraperitoneal injection of OVA plus cholera toxin. Although IgG2a Abs were lower in IKK $\beta^{\Delta \mathrm{IEC}}$ mice, the rest of Ig isotype and IgG subclass responses were similar to control C57BL/6 mice (Supplementary Figure S9A online). No difference was seen in lung inflammation after nasal antigen challenge, although IKK $\beta^{\Delta \mathrm{IEC}}$ mice exhibited higher mucus production than control mice (Supplementary Figure S9B online). These results underline the influence of the route of antigen sensitization on $\mathrm{Ab}$ responses and airway responses to subsequent antigen exposure or challenge.

\section{Gut-sensitized IL-17A-producing CD4 ${ }^{+} \mathrm{T}$ cells limit protection by IEC IKK $\beta$}

We next examined airway cytokine responses and lung functions after allergen challenges. IKK $\beta^{\Delta \mathrm{IEC}}$ and IKK $\beta^{\Delta \mathrm{Mye}}$ mice exhibited lower levels of lung eotaxin (C-C motif chemokine ligand 11) and eosinophil peroxidase mRNA responses 


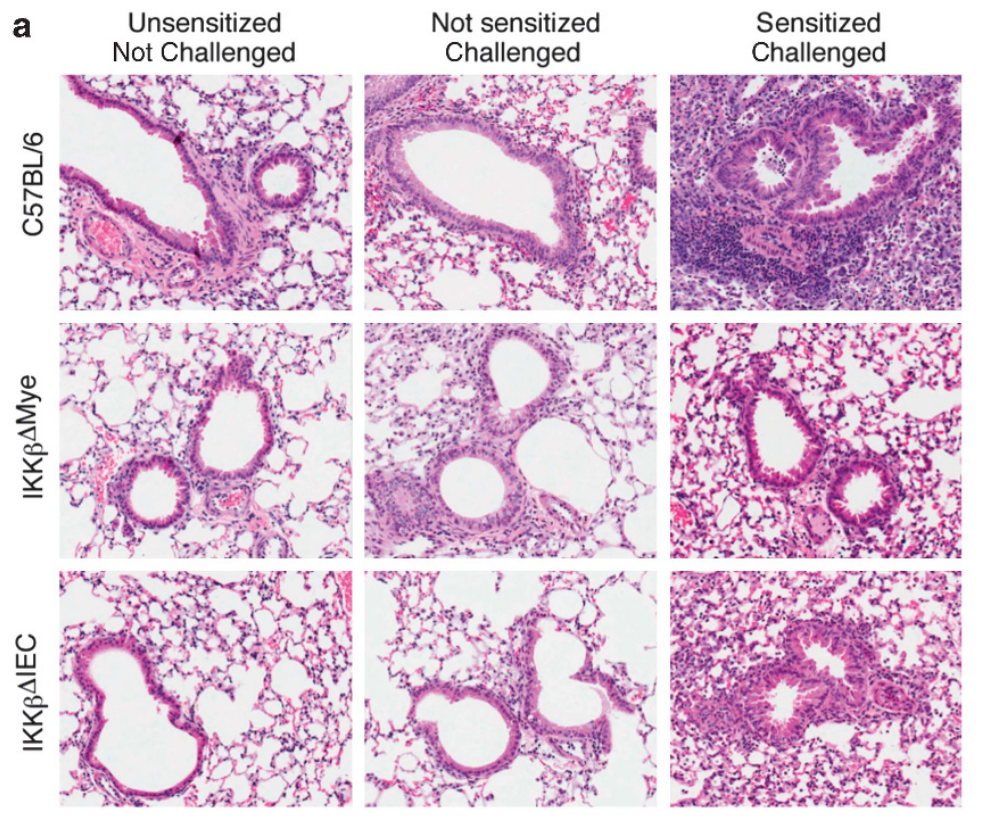

b

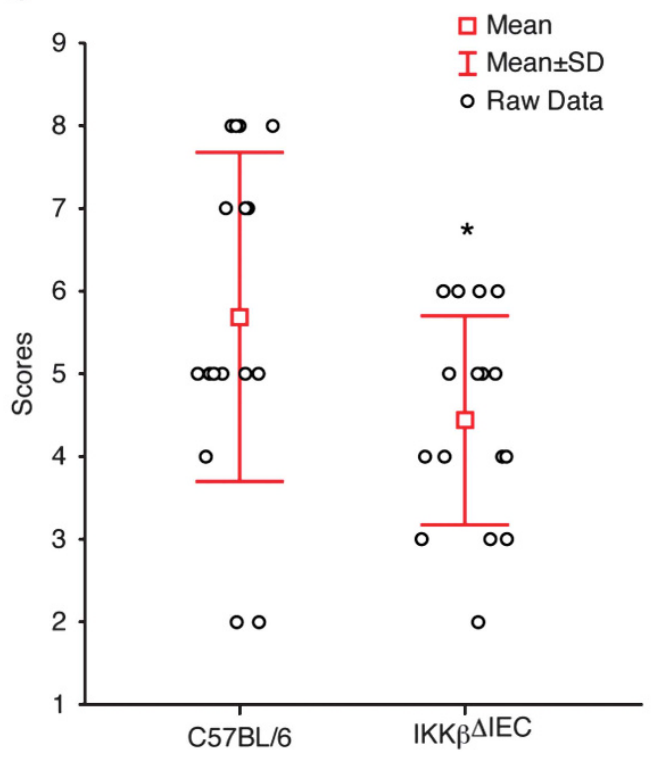

c
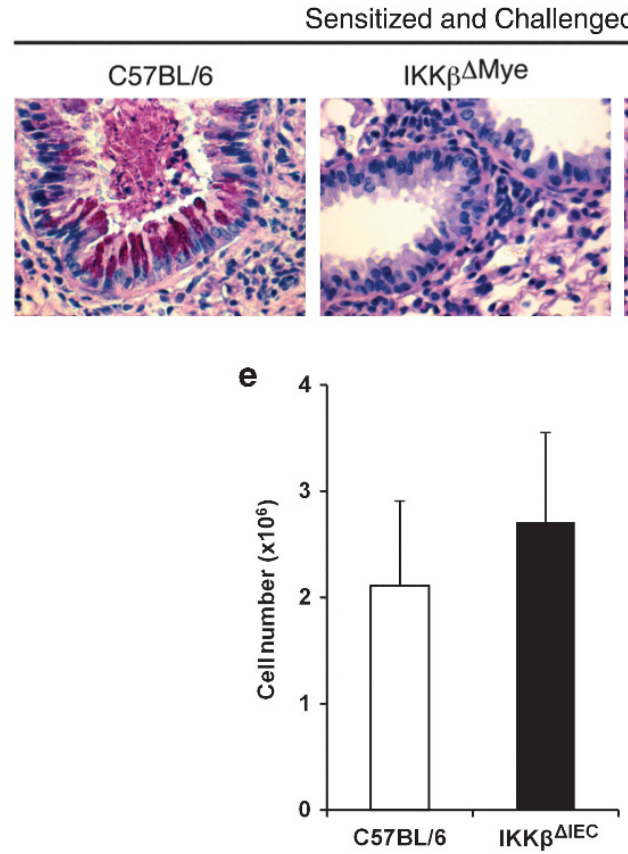

d
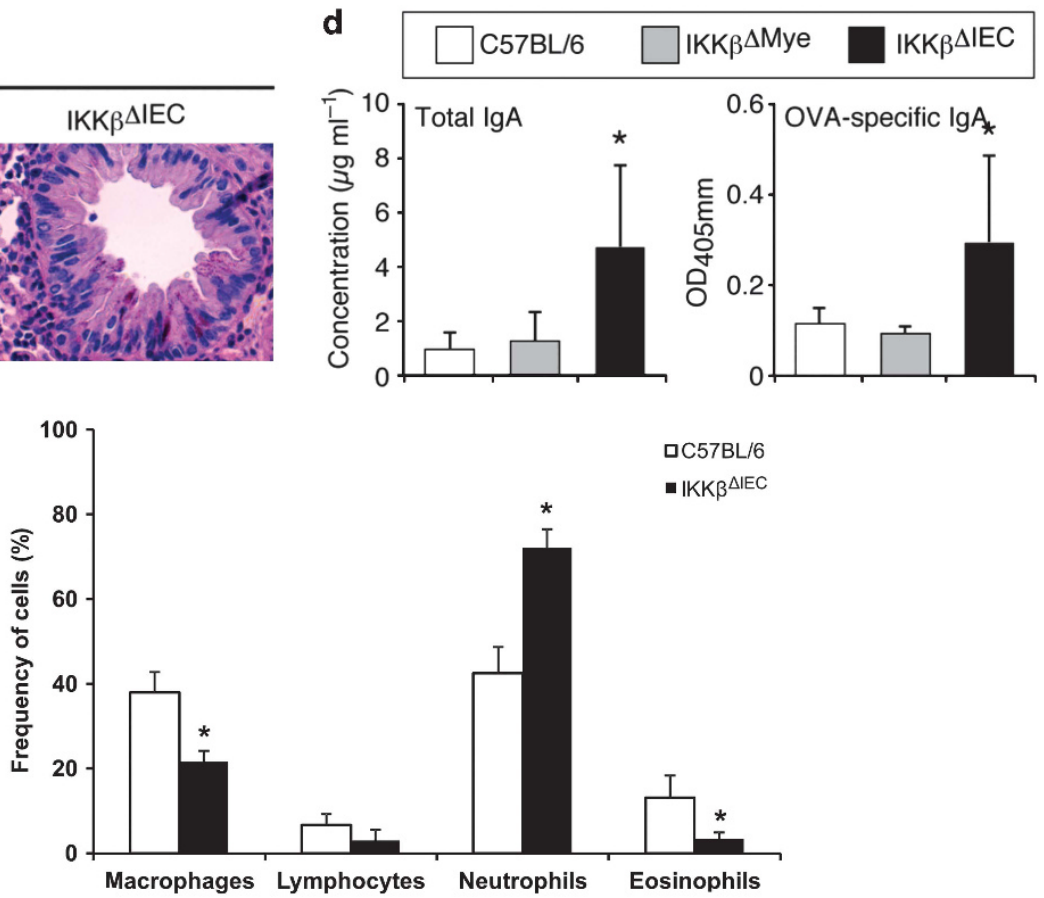

Figure 5 Inhibitor- $\mathrm{KB}$ kinase (IKK $\beta$ )-deficiency in intestinal epithelial cells (IECs) limits lung allergic inflammation in orally sensitized mice. (a) Hematoxylin and eosin staining of lung sections $(\times 40)$. (b) Inflammation scores in the lungs of C57BL/6 and IKK $\beta^{\Delta I E C}$ mice. (c) Tissues were stained with periodic acid-Schiff and counterstained with hematoxylin and eosin to visualize mucus $(\times 400)$. Each picture in a and $c$ is representative of three separate experiments, with 3-4 mice per group. (d) Total and ovalbumin (OVA)-specific immunoglobulin A (IgA) antibody levels, and (e) cell subsets in bronchoalveolar lavage fluids. The results are expressed as the mean \pm 1 s.d. and are from three experiments and five mice/group. $\left({ }^{\star} P<0.05\right.$ compared with control C57BL/6 mice). OD, optical density.

but enhanced IFN- $\gamma$, IL-17A, and MIP-2 (macrophage inflammatory protein-2) mRNA responses, with highest levels of response in IKK $\beta^{\Delta \mathrm{IEC}}$ mice, after nasal antigen challenge (Figure 6a). Furthermore, low or no IFN- $\gamma$ and IL-17 responses were measured in BAL of control mice after antigen challenge, whereas their levels were elevated in IKK $\beta^{\Delta \mathrm{IEC}}$ mice (Supplementary Figure S10). No mice developed signs of airway hyper-responsiveness without previous oral sensitization (Figure $\mathbf{6 b}$ ), and sensitized IKK $\beta^{\Delta \text { Mye }}$ mice were completely protected against airway hyper-responsiveness. Upon challenge, IKK $\beta^{\Delta \mathrm{IEC}}$ mice developed airway hyper-responsiveness responses, which were not statistically different from control C57BL/6 mice (Figure 6c). Interestingly, nasal treatment with anti-IL-17A mAbs reduced airway hyper-responsiveness in 
a
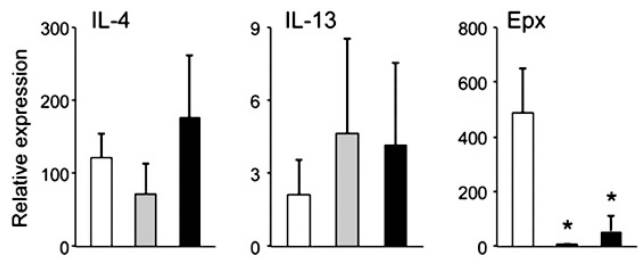

b $\quad 77-0-C 57 B L / 6$

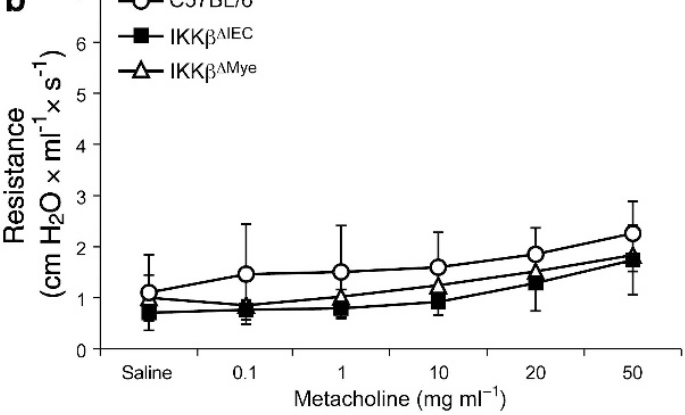

C

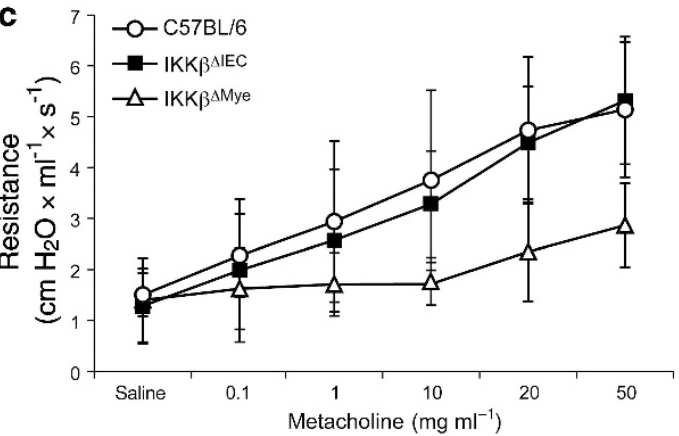

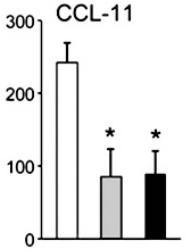
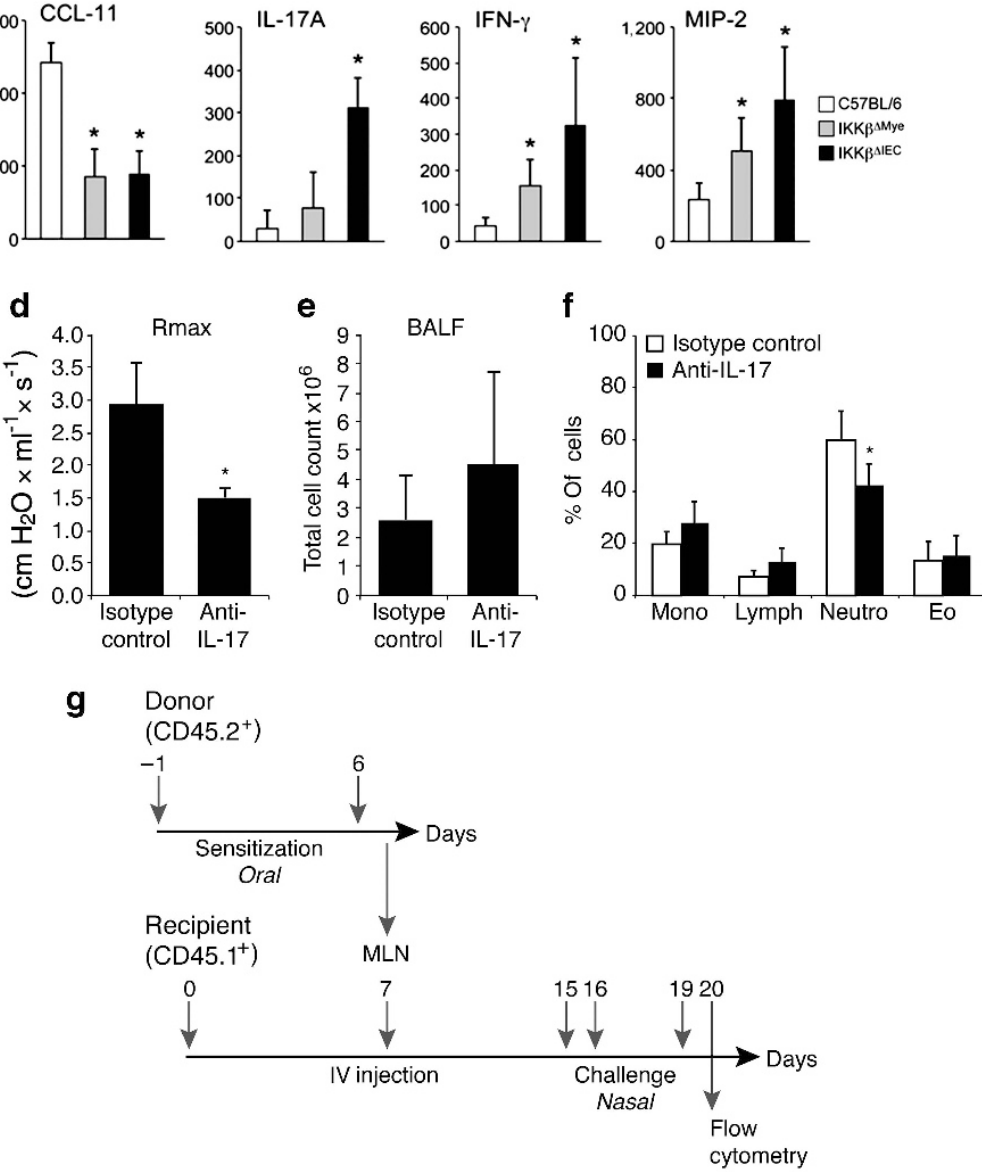

\begin{tabular}{|l|c|c|}
\cline { 2 - 3 } \multicolumn{1}{l|}{} & $\begin{array}{c}\text { Injection of } \mathrm{MLN} \\
\text { from } \mathrm{C} 57 \mathrm{BL} / 6\end{array}$ & $\begin{array}{c}\text { Injection of } \mathrm{MLN} \\
\text { from IKK } \beta \Delta \mathrm{IEC}\end{array}$ \\
\hline $\mathrm{CD} 3^{+} \mathrm{CD} 4{ }^{+} \mathrm{CD} 45.2^{+}$ & $19.5 \pm 4.7$ & $44.1 \pm 2.7^{*}$ \\
\hline $\mathrm{CD} 4{ }^{+} \alpha 4 \beta 7^{+} \mathrm{CD} 45.2^{+}$ & $87.4 \pm 0.5$ & $94.5 \pm 1.2^{* *}$ \\
\hline $\mathrm{CD} 4{ }^{+} \mathrm{CCR}{ }^{+}{ }^{+} \mathrm{CD} 45.2^{+}$ & $1.65 \pm 0.2$ & $3.6 \pm 0.7^{*}$ \\
\hline
\end{tabular}

Figure 6 Gut-sensitized interleukin (IL)-17A-producing CD4 ${ }^{+}$T cells limit the protective effect of immunoglobulin A antibodies in the airways of IKK $\beta^{\Delta I E C}$ (deletion of inhibitor-KB kinase (IKK $\beta$ ) in intestinal epithelial cells (IECs)) mice. (a-c) Mice were orally sensitized on days 0 and 14 and nasally challenged on days 15, 16, and 19. (a) Cytokines, chemokines, and neutrophil peroxidase mRNA responses in lung tissues on day 20. Results are expressed as mean \pm s.d. of three separate experiments, with four mice per group. $\left({ }^{\star} P<0.05\right.$ compared with control C57BL/6 mice).

(b) Airway hyper-reactivity after nasal challenge of naive mice. (c) Airway hyper-reactivity after nasal challenge (day 20) of orally sensitized mice. (d-f) Responses to anti-IL-17A treatment. (d) Airway hyper-reactivity, (e) total number of cells and (f) immune cell populations in bronchoalveolar lavage (BAL). Results are expressed as mean \pm s.d. of 5 mice per group. ( $\left.{ }^{\star} P<0.05\right)$. (g, h) Adoptive transfers of mesenteric lymph node (MLN) cells. (g) Timeline of adoptive transfer experiments. (h) Frequency of donor (CD45.2) CD4 + T cells expressing $\alpha 4 \beta 7$ and CCR9 (C-C motif chemokine receptor 9). Results are expressed as the mean \pm one s.d. and are from four separate experiments. $\left({ }^{*} P<0.05 ;{ }^{* *} P<0.01\right)$. CCL, C-C motif chemokine ligand; Epx, eosinophil peroxidase; IFN, interferon; IV, intravenous; MIP, macrophage inflammatory protein.

IKK $\beta^{\Delta I E C}$ mice (Figure $6 \mathbf{d}$ ) and the percentage of neutrophils in BALs (Figure 6e,f).

Finally, we adoptively transferred MLN cells of orally sensitized control $\mathrm{C} 57 \mathrm{BL} / 6$ and IKK $\beta^{\Delta \mathrm{IEC}}$ mice into naive $\mathrm{CD} 45.1^{+}$congenic recipient mice (Figure 6g). Analysis of lung cells after nasal antigen challenge showed a higher number of donor $\mathrm{CD}^{+}{ }^{+} \mathrm{CD} 4{ }^{+} \mathrm{CD} 45.2^{+}$cells in recipients of cells from IKK $\beta^{\Delta \mathrm{IEC}}$ mice (Figure 6h). A larger number of these donor $\mathrm{CD}^{+}{ }^{+} \mathrm{T}$ cells also expressed $\alpha 4 \beta 7$ and CCR9 (C-C motif chemokine receptor 9), suggesting that they were sensitized in the gut (Figure 6h).

\section{DISCUSSION}

Immune homeostasis is crucial at the mucosal surface of the gastrointestinal tract, which is constantly exposed to ingested antigens and commensal flora. Alteration of this homeostasis can lead to inflammatory bowel disease or food allergy. The higher incidence of asthma in inflammatory bowel diseases patients has suggested that these pathologies could share common etiological factors. ${ }^{32}$ Furthermore, growing evidence suggests that gut commensal microbiota can affect distant mucosal sites such as those of the airways and regulate innate and adaptive immune responses to respiratory virus 


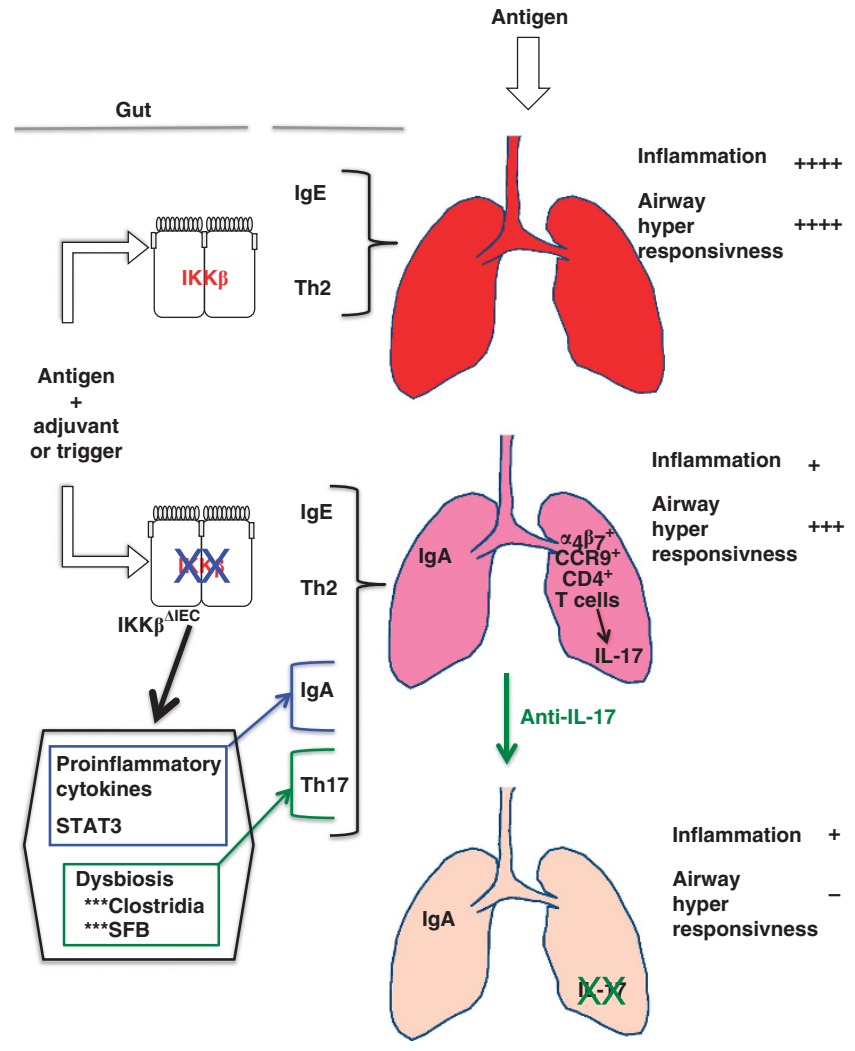

Figure 7 Regulation of pathogenic airway responses to allergens by inhibitor- $\mathrm{KB}$ kinase $(\mathrm{IKK} \beta)$ in intestinal epithelial cells (IECs). Allergic sensitization in the gut promotes antigen-specific immunoglobulin $\mathrm{E}(\operatorname{IgE})$ and T helper type 2 (Th2) responses, which will later induce allergic airway inflammation and airway hyper-responsiveness in the event of airway exposure to the same antigen. Loss of IKK $\beta$ in IECs does not alter immune homeostasis in the gut at the basal level. However, during allergic sensitization, lack of IKK $\beta$ signaling in IECs could enhance gut pro-inflammatory responses and promote dysbiosis. The change in cytokine milieu could support IgA antibodies (Abs), while alteration of the gut microbiota would support Th17 responses. Subsequent exposure of the airways to allergen will result in the accumulation of IgA Abs, which will protect against allergic inflammation. $\mathrm{CD} 4^{+} \mathrm{T}$ cells expressing the gut-homing receptors $\alpha 4 \beta 7$ and CCR9 (C-C motif chemokine receptor 9) and producing IL-17 are also recruited in the airways of IKK $\beta^{\Delta \mathrm{IEC}}$ mice upon antigen exposure. These cells more likely support hyperresponsivess of the airways to antigen exposure, and could be suppressed by treatment with anti-IL-17A Ab.IL, interleukin; SFB, segmented filamentous bacteria; STAT, signal transducer and activator of transcription factor.

infection $^{30,33}$ and allergic airway inflammation. ${ }^{34}$ Using genetically modified mice with cell-specific alteration of IKK $\beta$, we found that depletion of IKK $\beta$-NFKB signaling in IECs alters the microbial community in the gut, reshapes immune responses to food allergens, and regulates allergic responses in the airways via its effect on $\operatorname{IgA~Ab}$ and Th17 cell responses.

Allergic sensitization to food antigens can be modeled by oral administration of antigen with cholera toxin as adjuvant. ${ }^{5,6,22}$ Cholera toxin can break oral tolerance and promote adaptive immunity by binding to IECs and stimulating inflammatory cytokines. ${ }^{35,36}$ The NF- $\mathrm{BB}$ pathway can mediate both pro- and anti-inflammatory effects, ${ }^{8,9}$ and alteration of the IKK $\beta$-NF- $\kappa B$ in IECs could either attenuate chronic or exacerbate acute gut inflammatory diseases. ${ }^{11}$ We clearly show that lack of
IKK $\beta$ in IECs did not prevent these cells from developing pro-inflammatory and pSTAT3 responses but also increased TGF- $\beta$ mRNA in IKK $\beta^{\Delta I E C}$ mice. The latter finding is significant, as bone marrow stromal cells were reported to suppress allergic responses via induction of TGF- $\beta{ }^{37}$ Intestinal bacteria have a role in the maturation of gut immune cells, ${ }^{15,27,28}$ and selected commensal bacteria support allergic responses. ${ }^{38}$ The Clostridium-related bacterium SFB not only promotes Th17 responses ${ }^{27,28}$ but is also known to support IgA Abs. ${ }^{39,40}$ It is important to indicate that Ig class switch to the IgA isotype requires IL- 6 and TGF- $\beta,{ }^{41}$ which also support the differentiation of Th17 cells. ${ }^{42}$ Our results clearly show that alteration of IKK $\beta$ signaling in IECs can reorganize the gut microbiota and increase the proportion of Clostridium species and SFB during allergic sensitization in our experimental model. Our findings are consistent with the reported role of SFB and suggest that this bacterium and other Clostridium sp. helped enhance Th17 and IgA Ab responses in IKK $\beta^{\Delta \mathrm{IEC}}$ mice.

Nasal exposure to antigen after allergic sensitization promotes asthma-like pathology with increased airway hyper-responsiveness, airway inflammation, eosinophilia, and mucus secretion. ${ }^{2,43}$ Despite similar levels of IgE Ab responses than control wild-type mice, IKK $\beta^{\Delta \mathrm{IEC}}$ mice only developed limited lung inflammation upon antigen challenge. The fact that only IKK $\beta^{\Delta \mathrm{IEC}}$ mice showed high level of IgA Abs and IgA-secreting cells in the airways support the notion that IgA Abs suppress allergic inflammation, ${ }^{31}$ possibly by neutralizing allergens in mucosal tissues.

Consistent with the reported role of alveolar macrophages in asthma-induced inflammation, ${ }^{44}$ their percentage was lower in $\mathrm{IKK} \beta^{\mathrm{IIEC}}$ mice than in control mice. Airway hyper-responsiveness and eosinophilia in mice were reported to be associated with a high number of $\mathrm{CD}_{103}{ }^{+}$dendritic cells. ${ }^{45}$ Our study suggests that these cells also have a role in pathologies associated with priming to food antigens in the gastrointestinal tract. IL-17A is a mucogenic cytokine, ${ }^{46,47}$ which regulates airway inflammation, ${ }^{48}$ and double-negative $\mathrm{T}$ cells, producing IFN- $\gamma$ and IL-17A, were reported to be the major responders in the lungs of mice during pulmonary infection with a live Francisella tularensis vaccine. ${ }^{49}$ We show that $\mathrm{CD} 4{ }^{+} \mathrm{T}$ cells primed in mucosal tissues represent an important fraction of effector cells recruited in the lungs of IKK $\beta^{\Delta \mathrm{IEC}}$ mice upon antigen challenge and that they limit the protective effect of IgA Abs on allergic airway symptoms in this model via production of IL-17A.

We have shown that IKK $\beta$ deficiency in IECs promotes a cascade of events that ultimately protects the airways against the development of allergic inflammation (Figure 7). Our results suggest that future efforts for controlling allergic responses could include strategies that promote IgA Ab responses and prevent or reduce IL-17 responses.

\section{METHODS}

Mice. Mice in which IKK $\beta$-dependent NF- $\kappa \mathrm{B}$ signaling was selectively eliminated in the IECs $\left(\operatorname{IKK} \beta^{\Delta \mathrm{IEC}}\right.$ ) or myeloid cells $\left(\mathrm{IKK} \beta^{\Delta \mathrm{mye}}\right.$ ) were generated as previously described ${ }^{8,23}$ and bred in our facility. 
Control C57BL/6 mice were obtained from the NCI-Frederick and housed for 3-4 weeks with IKK $\beta$-deficient mice. Studies were performed on mice aged 10-12 weeks, in accordance with NIH and OSU IACUC guidelines.

Quantification of mRNA by real-time reverse transcriptase-PCR. Real-time reverse transcriptase-PCR was performed as previously described, ${ }^{50}$ and mRNA responses were expressed as mRNA relative expression $\left.=\left(1 / 2^{\Delta \mathrm{Ct}}\right) \times 100 \times 1000\right)$ where $\Delta \mathrm{Ct}=\mathrm{CP}_{\text {unknown }}-\mathrm{CP}_{\beta}$ actin.

Histology. Five 5 - $\mu \mathrm{m}$ paraffin sections were stained with hematoxylin and eosin, alone or with anti-pSTAT3 (Cell Signaling, Danvers, MA), anti-pNF- $\kappa$ B p65 (Santa Cruz Biotech, Dallas, TX), or subjected to periodic acid-Schiff staining.

Immunoblotting. Intestines were lysed, and proteins were separated by SDS-PAGE (sodium dodecyl sulfate-polyacrylamide gel electrophoresis). After transfer, PVDF (polyvinylidene difluoride) membranes were probed with anti-pSTAT3 (Cell Signaling) and an horseradish peroxidase-conjugated secondary $\mathrm{Ab}$. The membranes were re-probed with $\beta$-actin-specific $A b$ (Santa Cruz Biotech) and the relative ratios of $\mathrm{pSTAT} 3 / \beta$-actin were determined using Image J software (Bethesda, MD).

Oral treatment, oral sensitization, and nasal challenge of mice. For oral treatment, mice were deprived of food for $2 \mathrm{~h}$ and given $250 \mu \mathrm{l}$ of sodium bicarbonate $30 \mathrm{~min}$ before intragastric gavage of $10 \mu \mathrm{g}$ cholera toxin in $250 \mu \mathrm{l}$ of phosphate-buffered saline (PBS). Oral sensitization was performed on days 0 and 7 by intragastric gavage of $250 \mu \mathrm{l}$ of PBS containing $1 \mathrm{mg}$ of ovalbumin (OVA) and $10 \mu \mathrm{g}$ cholera toxin as adjuvant. Blood samples were collected on days 7 and 14. Nasal antigen challenges were performed on days 15, 16, and 19. For this purpose, mice were anesthetized by intraperitoneal injection of ketamine/ xylazine and administered $200 \mu \mathrm{g}$ of OVA in PBS. In selected experiments, mice were nasally treated ( $10 \mu \mathrm{g}$ per dose) with an antiIL-17A mAb or isotype control Ab (R\&D Systems, Minneapolis, MN).

Analysis of gut microbiota. Bacterial tag-encoded FLX amplicon pyrosequencing (Roche Titanium 454 FLX pyrosequencing, Branford, CT) was used for detection and identification of the primary populations of microbes in fecal pellet samples. For identification of SFB, blast search was performed with the fasta sequences against Candidatus Arthromitus (taxid:49082) genome sequences (Candidatus Arthromitus sp. SFB-mouse-Yit and Candidatus Arthromitus sp. SFB-mouse-Japan), using Megablast (optimized for highly similar sequences; $\geqslant 95 \%$ ) and E-values below 1e-15.

Fecal microbiota transplantation. Fecal material for microbiota transfer was prepared by using a modification of a previously described method. ${ }^{51}$ Briefly, freshly emitted fecal pellets were homogenized by vortexing in sterile PBS ( $1 \mathrm{ml}$ per $0.1 \mathrm{~g}$ of fecal material). After filtration of particulate matters, mice were gavage with $0.2 \mathrm{ml}$ of the suspension.

Antigen-specific CD4 ${ }^{+}$T cell cytokine responses. Spleens and MLN were collected 1 week after the last immunization and mononuclear cells were restimulated in vitro with OVA $\left(1 \mathrm{mg} \mathrm{ml}^{-1}\right)$ as previously reported. ${ }^{52}$ After 5 days of culture, levels of Th1 (IFN- $\gamma$ ), Th2 (IL-4, IL5, IL-10), or Th17 (IL-17A) cytokines in supernatants were determined by enzyme-linked immunosorbent assay using mAb pairs and cytokine standards (BD Biosciences, San Jose, CA or R\&D Systems).

Antigen-specific $\mathbf{A b}$ responses and total IgA levels. OVA-specific $\mathrm{Ab}$ responses were measured by enzyme-linked immunosorbent assay as previously described. ${ }^{52}$ Total IgA levels were determined by enzyme-linked immunosorbent assay and $\operatorname{IgA}$ standards. The frequency of IgA-secreting cells were evaluated by ELISPOT. ${ }^{53}$

Analysis of lung functions and airway responses to metacholine challenge. Mechanical properties of the mouse lung were assessed using the forced-oscillation technique ${ }^{54}$ and a flexiVent computer-controlled piston ventilator (SCIREQ, Montreal, QC, Canada). Mice were exposed to increasing doses of metacholine $(0.1,1$, 10,20 , and $50 \mathrm{mg} \mathrm{ml}^{-1}$ ) in sterile normal saline, ${ }^{54}$ and total lung resistance were recorded.

Adoptive transfer. Cells $\left(8 \times 10^{6}\right)$ from control C57BL/6 (CD45.2) or IKK $\beta^{\Delta \mathrm{IEC}}(\mathrm{CD} 45.2)$ were injected intravenously into congenic CD45.1 mice. Donor and recipient cells were discriminated in tissues of recipient mice by flow cytometry using CD45.1 and CD45.2 specific mAbs (BD Biosciences).

BALs. BAL fluids were obtained via cannulation of the exposed trachea, by infusion of $600 \mu \mathrm{l}$ of sterile PBS through a 22-gauge catheter into the lungs. ${ }^{5}$

Analysis of cell populations in lung tissues. Whole-lung tissue was dissociated in $0.5 \mathrm{mg} \mathrm{ml}^{-1}$ collagenase type V (Sigma, St Louis, MO) for $15 \mathrm{~min}$ at $37^{\circ} \mathrm{C}$. Single-cell preparations were stained with one or a combination of the fluorescent anti-mouse Abs: anti-CD11b, anti-CD11c, anti-F4/80 anti-B220, anti-CD3, anti-CD4, anti-CD8, anti-CD103, anti- $\alpha 4 \beta 7$, and anti-CCR9 (BD Biosciences and eBiosciences, San Diego, CA) and analyzed by flow cytometry (Accuri Cytometers, San Jose, CA).

Statistics. Results are expressed as the mean \pm 1 s.d. Statistical significance was determined by Student's $t$-test or by analysis of variance followed by the Fisher Least Significant Difference Test. For analysis of mRNA responses, we used one-way analysis of variance, followed by Duncan's Multiple Range Test.. All statistical analyses were performed with the Statistica 9.0 software package (StatSoft, Tulsa, OK).

SUPPLEMENTARY MATERIAL is linked to the online version of the paper at http://www.nature.com/mi

\section{ACKNOWLEDGEMENTS}

Supported by grants from the National Institute of Health (R01 Al043197) and the OSU Food Innovation Center (to PNB), and a fellowship from Fondation Lelous, France (to AB-B). We thank Dr Kate Hayes-Ozello for editorial assistance, $\mathrm{Dr}$ Jessica Grieves for assistance with scoring of histology, Tim Vojt for help with graphic design, and Dr J Delton Hanson for review of the metagenomic data.

\section{DISCLOSURE}

The authors declare no conflict of interest.

c) 2014 Society for Mucosal Immunology

\section{REFERENCES}

1. Holgate, S.T. Pathophysiology of asthma: what has our current understanding taught us about new therapeutic approaches?. J. Allergy Clin. Immunol. 128, 495-505 (2011).

2. Sicherer, S.H. \& Sampson, H.A. Food allergy. J. Allergy Clin. Immunol. 125 (2 Suppl 2), S116-S125 (2010).

3. Broide, D.H. et al. Allergen-induced peribronchial fibrosis and mucus production mediated by lkappaB kinase beta-dependent genes in airway epithelium. Proc. Natl. Acad. Sci. USA 102, 17723-17728 (2005).

4. Ather, J.L., Hodgkins, S.R., Janssen-Heininger, Y.M. \& Poynter, M.E. Airway epithelial NF-kappaB activation promotes allergic sensitization to an innocuous inhaled antigen. Am. J. Respir. Cell Mol. Biol. 44, 631-638 (2011).

5. Fischer, R. et al. Oral and nasal sensitization promote distinct immune responses and lung reactivity in a mouse model of peanut allergy. Am. J. Pathol. 167, 1621-1630 (2005).

6. Oyoshi, M.K. et al. Epicutaneous challenge of orally immunized mice redirects antigen-specific gut-homing Tcells to the skin. J. Clin. Invest. 121, 2210-2220 (2011). 
7. Vallabhapurapu, S. \& Karin, M. Regulation and function of NF-kappaB transcription factors in the immune system. Annu. Rev. Immunol. 27, 693-733 (2009).

8. Greten, F.R. et al. NF-kappaB is a negative regulator of IL-1 beta secretion as revealed by genetic and pharmacological inhibition of IKK Kbeta. Cel/ 130, 918-931 (2007).

9. Lawrence, T., Gilroy, D.W., Colville-Nash, P.R. \& Willoughby, D.A. Possible new role for NF-kappaB in the resolution of inflammation. Nat. Med. 7, 1291-1297 (2001).

10. Fong, C.H. et al. An antiinflammatory role for IKKbeta through the inhibition of "classical" macrophage activation. J. Exp. Med. 205, 1269-1276 (2008).

11. Eckmann, L. et al. Opposing functions of IKKbeta during acute and chronic intestinal inflammation. Proc. Natl. Acad. Sci. USA 105, 15058-15063 (2008).

12. Zaph, C. et al. Epithelial-cell-intrinsic IKK-beta expression regulates intestinal immune homeostasis. Nature 446, 552-556 (2007).

13. Backhed, F., Ley, R.E., Sonnenburg, J.L., Peterson, D.A. \& Gordon, J.I. Host-bacterial mutualism in the human intestine. Science 307, 1915-1920 (2005).

14. Bouma, G. \& Strober, W. The immunological and genetic basis of inflammatory bowel disease. Nat. Rev. Immunol. 3, 521-533 (2003).

15. Chung, $\mathrm{H}$. et al. Gut immune maturation depends on colonization with a host-specific microbiota. Cell 149, 1578-1593 (2012).

16. Macpherson, A.J. \& Harris, N.L. Interactions between commensal intestinal bacteria and the immune system. Nat. Rev. Immunol. 4, 478-485 (2004).

17. Rodriguez, B. et al. Infant gut microbiota is protective against cow's milk allergy in mice despite immature ileal T-cell response. FEMS Microbiol. Ecol. 79, 192-202 (2012).

18. Bjorksten, B., Sepp, E., Julge, K., Voor, T. \& Mikelsaar, M. Allergy development and the intestinal microflora during the first year of life. J. Allergy Clin. Immunol. 108, 516-520 (2001).

19. Turnbaugh, P.J. et al. A core gut microbiome in obese and lean twins. Nature 457, 480-484 (2009).

20. Greenblum, S., Turnbaugh, P.J. \& Borenstein, E. Metagenomic systems biology of the human gut microbiome reveals topological shifts associated with obesity and inflammatory bowel disease. Proc. Natl. Acad. Sci. USA 109, 594-599 (2012).

21. Elinav, E. et al. NLRP6 inflammasome regulates colonic microbial ecology and risk for colitis. Cell 145, 745-757 (2011).

22. Dunkin, D., Berin, M.C. \& Mayer, L. Allergic sensitization can be induced via multiple physiologic routes in an adjuvant-dependent manner. J. Allergy Clin. Immunol. 128, 1251-1258.e2 (2011).

23. Chen, L.W., Egan, L., Li, Z.W., Greten, F.R., Kagnoff, M.F. \& Karin, M. The two faces of IKK and NF-kappaB inhibition: prevention of systemic inflammation but increased local injury following intestinal ischemiareperfusion. Nat. Med. 9, 575-581 (2003).

24. Snel, J. et al. Comparison of $16 \mathrm{~S}$ rRNA sequences of segmented filamentous bacteria isolated from mice, rats, and chickens and proposal of "Candidatus Arthromitus". Int. J. Syst. Bacteriol. 45, 780-782 (1995).

25. Umesaki, Y., Okada, Y., Imaoka, A., Setoyama, H. \& Matsumoto, S. Interactions between epithelial cells and bacteria, normal and pathogenic. Science 276, 964-965 (1997).

26. Prakash, T. et al. Complete genome sequences of rat and mouse segmented filamentous bacteria, a potent inducer of th17 cell differentiation. Cell Host Microbe 10, 273-284 (2011).

27. Gaboriau-Routhiau, V. et al. The key role of segmented filamentous bacteria in the coordinated maturation of gut helper $\mathrm{T}$ cell responses. Immunity 31, 677-689 (2009).

28. Ivanov, I.I. et al. Induction of intestinal Th17 cells by segmented filamentous bacteria. Cell 139, 485-498 (2009).

29. Bashir, M.E., Louie, S., Shi, H.N. \& Nagler-Anderson, C. Toll-like receptor 4 signaling by intestinal microbes influences susceptibility to food allergy. J. Immunol. 172, 6978-6987 (2004).

30. Ichinohe, T. et al. Microbiota regulates immune defense against respiratory tract influenza A virus infection. Proc. Natl. Acad. Sci. USA 108, 5354-5359 (2011).

31. Smits, H.H. et al. Cholera toxin B suppresses allergic inflammation through induction of secretory IgA. Mucosal Immunol. 2, 331-339 (2009).

32. Weng, X., Liu, L., Barcellos, L.F., Allison, J.E. \& Herrinton, L.J. Clustering of inflammatory bowel disease with immune mediated diseases among members of a northern california-managed care organization. Am. J. Gastroenterol. 102, 1429-1435 (2007).

33. Abt, M.C. et al. Commensal bacteria calibrate the activation threshold of innate antiviral immunity. Immunity 37, 158-170 (2012).

34. Hill, D.A. et al. Commensal bacteria-derived signals regulate basophil hematopoiesis and allergic inflammation. Nat. Med. 18, 538-546 (2012).

35. Bromander, A.K., Kjerrulf, M., Holmgren, J. \& Lycke, N. Cholera toxin enhances alloantigen presentation by cultured intestinal epithelial cells. Scand. J. Immunol. 37, 452-458 (1993).

36. Bandyopadhaya, A., Sarkar, M. \& Chaudhuri, K. Transcriptional upregulation of inflammatory cytokines in human intestinal epithelial cells following Vibrio cholerae infection. FEBS J. 274, 4631-4642 (2007).

37. Nemeth, K. et al. Bone marrow stromal cells use TGF-beta to suppress allergic responses in a mouse model of ragweed-induced asthma. Proc. Natl. Acad. Sci. USA 107, 5652-5657 (2010).

38. Bisgaard, $\mathrm{H}$. et al. Reduced diversity of the intestinal microbiota during infancy is associated with increased risk of allergic disease at school age. J. Allergy Clin. Immunol. 128, 646-52.e1-646-52.e5 (2011).

39. Klaasen, H.L. et al. Apathogenic, intestinal, segmented, filamentous bacteria stimulate the mucosal immune system of mice. Infect. Immun. 61, 303-306 (1993).

40. Talham, G.L., Jiang, H.Q., Bos, N.A. \& Cebra, J.J. Segmented filamentous bacteria are potent stimuli of a physiologically normal state of the murine gut mucosal immune system. Infect. Immun. 67, 1992-2000 (1999).

41. Suzuki, K. \& Fagarasan, S. Diverse regulatory pathways for IgA synthesis in the gut. Mucosal Immunol. 2, 468-471 (2009).

42. Weaver, C.T., Hatton, R.D., Mangan, P.R. \& Harrington, L.E. IL-17 family cytokines and the expanding diversity of effector Tcell lineages. Annu. Rev. Immunol. 25, 821-852 (2007).

43. Salvatori, N. et al. Asthma induced by inhalation of flour in adults with food allergy to wheat. Clin. Exp. Allergy 38, 1349-1356 (2008).

44. Song, C. et al. IL-17-producing alveolar macrophages mediate allergic lung inflammation related to asthma. J. Immunol. 181, 6117-6124 (2008).

45. Sung, S.S., Fu, S.M., Rose, C.E. Jr., Gaskin, F., Ju, S.T. \& Beaty, S.R. A major lung CD103 (alphaE)-beta7 integrin-positive epithelial dendritic cell population expressing Langerin and tight junction proteins. J. Immunol. 176, 2161-2172 (2006).

46. Chen, Y., Thai, P., Zhao, Y.H., Ho, Y.S., DeSouza, M.M. \& Wu, R. Stimulation of airway mucin gene expression by interleukin (IL)-17 through IL-6 paracrine/autocrine loop. J. Biol. Chem. 278, 17036-17043 (2003).

47. Lukacs, N.W., Smit, J.J., Mukherjee, S., Morris, S.B., Nunez, G. \& Lindell, D.M. Respiratory virus-induced TLR7 activation controls IL-17associated increased mucus via IL-23 regulation. J. Immunol. 185, 2231-2239 (2010).

48. Durrant, D.M., Gaffen, S.L., Riesenfeld, E.P., Irvin, C.G. \& Metzger, D.W. Development of allergen-induced airway inflammation in the absence of T-bet regulation is dependent on IL-17. J. Immunol. 183, 5293-5300 (2009).

49. Cowley, S.C., Meierovics, A.I., Frelinger, J.A., Iwakura, Y. \& Elkins, K.L. Lung CD4-CD8- double-negative T cells are prominent producers of $\mathrm{IL}-17 \mathrm{~A}$ and IFN-gamma during primary respiratory murine infection with Francisella tularensis live vaccine strain. J. Immunol. 184, 5791-5801 (2010).

50. Duverger, A. et al. Contributions of edema factor and protective antigen to the induction of protective immunity by Bacillus anthracis edema toxin as an intranasal adjuvant. J. Immunol. 185, 5943-5952 (2010).

51. Turnbaugh, P.J., Ridaura, V.K., Faith, J.J., Rey, F.E., Knight, R. \& Gordon, J.I. The effect of diet on the human gut microbiome: a metagenomic analysis in humanized gnotobiotic mice. Sci. Transl. Med. 1, 6ra14 (2009).

52. Duverger, A. et al. Bacillus anthracis edema toxin acts as an adjuvant for mucosal immune responses to nasally administered vaccine antigens. J. Immunol. 176, 1776-1783 (2006).

53. Boyaka, P.N. et al. Chimeras of labile toxin one and cholera toxin retain mucosal adjuvanticity and direct Th cell subsets via their B subunit. J. Immunol. 170, 454-462 (2003).

54. Aeffner, F., Traylor, Z.P., Yu, E.N. \& Davis, I.C. Double-stranded DNA induces similar pulmonary dysfunction to respiratory syncytial virus in BALB/c mice. Am. J. Physiol. Lung Cell. Mol. Physiol. 301, L99-L109 (2011). 